\title{
Transmission dynamics and vaccination strategies for Crimean-Congo haemorrhagic fever virus in Afghanistan: a modelling study
}

\author{
Juan F Vesga ${ }^{1,2}$, Madeleine H A Clark ${ }^{3}$, Edris Ayazi ${ }^{4}$, Andrea Apolloni ${ }^{5,6}$, Toby Leslie ${ }^{7}$, W
} John Edmunds ${ }^{1,2}$, Raphaëlle Métras ${ }^{1,2,8}$

Correspondence: juan.vesga-gaviria@Ishtm.ac.uk

\section{Affiliations:}

${ }^{1}$ Centre for Mathematical Modelling of Infectious Diseases, London School of Hygiene \& Tropical Medicine, Keppel Street, London, WC1E 7HT, UK;

${ }^{2}$ Department of Infectious Disease Epidemiology, London School of Hygiene \& Tropical Medicine, Keppel Street, London, WC1E 7HT, UK;

${ }^{3}$ Integrated Understanding of Health, Research Strategy and Programmes, Biotechnology and Biosciences Research Council, Polaris House, Swindon, SN2 1FL, UK

${ }^{4}$ Ministry of Public Health, Massoud Square, Kabul, Afghanistan;

${ }^{5}$ CIRAD, UMR ASTRE, Montpellier, France;

${ }^{6}$ ASTRE, Univ Montpellier, CIRAD, INRA, Montpellier, France;

7 International Health, Mott MacDonald Ltd, 10 Fleet Place, London, EC4M7RB

8 INSERM, Sorbonne Université, Institut Pierre Louis d'Épidémiologie et de Santé Publique (Unité Mixte de Recherche en Santé 1136), 75012 Paris, France 
medRxiv preprint doi: https://doi.org/10.1101/2022.01.20.22269558; this version posted January 21, 2022. The copyright holder for this preprint (which was not certified by peer review) is the author/funder, who has granted medRxiv a license to display the preprint in

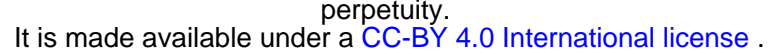

\begin{abstract}
Background

Crimean-Congo haemorrhagic fever virus (CCHFV) is a highly pathogenic virus for which a safe and effective vaccine is not yet available, despite being considered a priority emerging pathogen. Understanding transmission patterns and the use of potential effective vaccines are central elements of the future plan against this infection.
\end{abstract}

\title{
Methods
}

We developed a series of models of transmission amongst livestock, and spillover infection into humans. We use real-world human and animal data from a CCHFV endemic area in Afghanistan (Herat) to calibrate our models. We assess the value of environmental drivers as proxy indicators of vector activity, and select the best model using deviance information criteria. Finally we assess the impact of vaccination by simulating campaigns targeted to humans or livestock, and to high-risk subpopulations (i.e, farmers).

\section{Findings}

Saturation deficit is the indicator that better explains tick activity trends in Herat. Recent increments in reported CCHFV cases in this area are more likely explained by increased surveillance capacity instead of changes in the background transmission dynamics. Modelling suggests that clinical cases only represent 31\% (95\% Crl 28\%-33\%) of total infections in this area. Vaccination campaigns targeting humans would result in a much larger impact than livestock vaccination (266 vs 31 clinical cases averted respectively) and a more efficient option when assessed in courses per case averted (35 vs 431 respectively). Targeted vaccination to farmers is impactful and more efficient, resulting in 19 courses per case averted (95\% Crl 762) compared to targeting the general population (35 95\% Crl 16-107)

\section{Interpretation}

CCHFV is endemic in Herat, and transmission cycles are well predicted by environmental drivers like saturation deficit. Vaccinating humans is likely to be more efficient and impactful than animals, and importantly targeted interventions to high risk groups like farmers can offer a more efficient approach to vaccine roll-out.

\section{Funding}

W.J.E., JFV and MHAC were funded by the Department of Health and Social Care using UK Aid funding managed by the National Institute for Health Research (Vaccine Efficacy Evaluation for Priority Emerging Diseases: PR-OD-1017-20002). The views expressed in this publication are those of the authors and not necessarily those of the Department of Health and Social Care. 
medRxiv preprint doi: https://doi.org/10.1101/2022.01.20.22269558; this version posted January 21, 2022. The copyright holder for this preprint (which was not certified by peer review) is the author/funder, who has granted medRxiv a license to display the preprint in

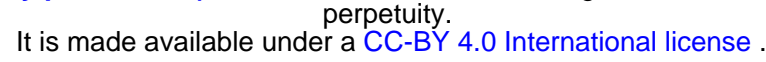

\section{Introduction}

Crimean-Congo haemorrhagic fever virus (CCHFV) is an emerging tick-borne zoonotic pathogen which can lead to cases of fatal haemorrhagic fever in humans. In recent years, outbreaks of CCHF in humans have increased in frequency, and is the virus now endemic in several countries in the Middle East, Africa, Asia, and Southeast Europe. The wide geographical distribution of tick species which are able to harbour the virus provide added concern that the disease may spread further afield. This, and CCHF's epidemic-proneness has led the World Health Organisation to include CCHFV in the group of priority pathogens for research and development into improved vaccines, therapeutics and diagnostics ${ }^{1}$.

The transmission dynamics of CCHFV is complex due to the interplay between environmental factors affecting tick activity and their life cycles, the asymptomatic transmission within multiple vertebrate species (wild and livestock), and behavioural factors behind the risk of spillover into humans. Hyalomma spp. are the main vectors of CCHFV, and Hyalomma marginatum complex the most frequently associated species. Tick activity has been associated with environmental and meteorological variations, which might drive seasonal transmission patterns ${ }^{2}$. Hyalomma spp, specifically, thrives during the hot summer months in dry weathers, however its adaptability to colder temperatures has been also reported, explaining in part the expanding geographical area of influence of CCHFV ${ }^{2-4}$. Emergence of CCHFV has also been linked to importation of livestock species ${ }^{5}$ and changes in agricultural activities, which affect the habitats of intermediate hosts of CCHFV ${ }^{2,6}$.

Despite the absence of a safe and effective licensed vaccine against CCHFV, the development of a stable animal model ${ }^{7}$ has meant that several vaccine candidates are now being studied. Inactivated virus ${ }^{8,9}$, DNA ${ }^{10}$, mRNA ${ }^{11}$, and plant-expressed glycoprotein formulations ${ }^{12}$ amongst others, are part of the current development pipeline. Inactivated vaccines have been routinely used in humans before in Bulgaria ${ }^{8}$, with reported reductions in incidence, but the lack of data on efficacy and safety on this formulation has prevented its wider use.

CCHFV is considered a priority emerging pathogen, but important gaps in our understanding of transmission dynamics into humans and a formal assessment of the potential impact of vaccines are still necessary to advance a global research agenda and for developing a roadmap for CCHF.

Human CCHFV cases have been reported in Afghanistan at least since 1998, first in Takhar province, and later in Herat province where most of the cases have emerged since $2002{ }^{13}$. However, in recent years the distribution of cases has extended to most provinces in the country. Neighbouring countries such as Pakistan, Iran, Turkmenistan, and Tajikistan, also report annual cases of CCHFV. These countries are located in the ecological range of activity of Hyalomma spp. Transboundary livestock movement is thought to aid transmission ${ }^{14}$.

Here we present a first approach to modelling CCHFV transmission amongst livestock and from livestock into humans, in Herat, an endemic area of Afghanistan.

Herat reported CCHFV outbreaks in 2008 and 2017 with an estimated case fatality ratio (CFR) ranging from $22 \%$ to $33 \%$ in humans ${ }^{15,16}$. Seroprevalence studies carried out in the area have 
medRxiv preprint doi: https://doi.org/10.1101/2022.01.20.22269558; this version posted January 21, 2022. The copyright holder for this preprint (which was not certified by peer review) is the author/funder, who has granted medRxiv a license to display the preprint in

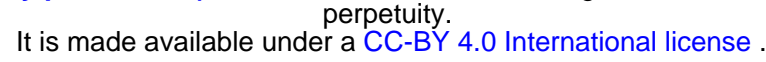

reported high IgG seroprevalence in livestock ( 75\%) and higher seroprevalence among humans involved in livestock activities (farming, animal husbandry, etc) ${ }^{17}$. High seroprevalence in livestock suggest endemic transmission in animal hosts, although further serological evidence is not available to confirm this. Furthermore, the drivers behind trends in human spillover are not fully understood and the possible seasonality driven by environmental factors has not been assessed yet.

In this work, we aim to shed light on the main factors driving CCHFV transmission in western Afghanistan and ascertain whether the disease is endemic or epidemic, as a case study for $\mathrm{CCHFV}$ in general. We expand this case to explore the impact of selected vaccination strategies on disease incidence and mortality reduction in humans.

\section{Methods}

\section{Mathematical model}

We model CCHFV transmission in livestock, and from livestock to humans in two steps (Figure 1). In step 1, we define a deterministic susceptible-infected-recovered-susceptible (SIRS) model structure for livestock, stratified in five yearly age groups. A full description and mathematical notation of the entire system can be found in section 2 of supplementary information, but we describe here the process to incorporate environmental drivers into the force of infection for livestock. Transmission between animals occurs as a function of prevalence of infectious livestock and a driving environmental factor (e.g., saturation deficit, soil temperature) which acts as a surrogate indicator of tick activity. Hence in livestock, we define the force of infection as following,

$\lambda_{L}=\beta_{L} \frac{\sum_{a} I_{a}}{N_{L}}$

Where the term $\frac{\sum_{a} I_{a}}{N_{L}}$ represents the prevalence of infectious livestock at any given point in time, while $\beta_{L}$ is the transmission coefficient representing the combination of transmission likelihoods between tick and livestock, and tick activity. We can also write,

$\beta_{L}=\frac{R_{L}(t)}{D_{i L}}$

Where $R_{L}(t)$ is the reproduction number in livestock at each point in time $t$, and is defined as a function of the environmental driver used, as explained in the supporting information; $D_{i L}$ is the duration of the infectious period in livestock.

Since environmental drivers are here reflecting a measure of tick activity, we incorporate the conditions that best reflect tick activity in relation to each driver. For a temperature dependent reproduction number, for example, we describe a system where adult Hyalomma spp. activity occurs above $12^{\circ} \mathrm{C}^{2,18}$ and increases as temperature increases. Once temperature reaches above $30^{\circ} \mathrm{C}$, ticks prefer to bury into soil ${ }^{19}$, thus we write a function for declining transmission (see supplementary information). 
medRxiv preprint doi: https://doi.org/10.1101/2022.01.20.22269558; this version posted January 21, 2022. The copyright holder for this preprint (which was not certified by peer review) is the author/funder, who has granted medRxiv a license to display the preprint in

perpetuity.
It is made available under a CC-BY 4.0 International license.

In step 2, we use a stochastic susceptible-exposed-infected-recovered-susceptible (SEIRS) model for transmission of CCHFV from livestock into humans. We define the process of transmission with a random binomial process where probability of event depends on infection prevalence in livestock at each time $t$ and a risk multiplication factor to capture excess risk among farmers (assumed to be the high risk group). Human to human transmission is not modelled, assuming that this component is not relevant in sustaining CCHFV outbreaks. A detailed model specification and mathematical expressions can be found in the Appendix.

The model is fitted to data by calibrating relevant model parameters within a Bayesian framework. A full description of the model calibration and model-fit diagnostics can be found in supplementary information (section 5, Figs S5 -S7). In Table 1, we present the list of model parameters and the calibrated values. We compare our model output against target data on age stratified CCHFV seroprevalence in livestock, risk stratified seroprevalence in humans (i.e., farmers and other occupations), and time series of reported CCHFV cases in humans. A summary of target data used in calibration can be found in Table S1.

This study has obtained approval from the ethics committee at the London School of Hygiene and Tropical Medicine (Reference number: 26612). All the data used has been aggregated and anonymised.

\section{Exploring epidemiological and environmental drivers}

In the absence of tick activity data, we use the environmental factors that influence tick dynamics and its trends over the year. These factors are incorporated as drivers of transmission of CCHFV between livestock. To explore the different environmental drivers and potential epidemiological conditions that better explain the observed trends in Herat's data, we systematically compare models in two steps.

In step 1, we calibrate the models four times, each time using a different environmental driver, namely soil temperature, saturation deficit, relative humidity and normalized difference vegetation index (NDVI).

We retrieved the relevant data for the specific geographical location and time period from available sources. Each driver, its source and relevance in tick activity can be found in Table 2 (For further details on construction of these indicators see supporting information).

In step 2, we further explore assumptions about the epidemiological factors behind the trends in reported human CCHF cases over the years. For this, we use the best model selected in step 1, and test three potential scenarios that have been hypothesised elsewhere ${ }^{13,15}$, namely: A) Increments in CCHF reported cases reflect increment in reporting capacity (baseline assumption); B) Increased influx of livestock from other endemic regions (with a fixed reporting capacity); and, C) Increased influx of livestock from other endemic regions, and increased reporting capacity combined.

In both steps 1 and 2, the most appropriate model is selected using a Deviance Information Criterion (DIC) approach.

\section{Vaccination strategies}


medRxiv preprint doi: https://doi.org/10.1101/2022.01.20.22269558; this version posted January 21, 2022. The copyright holder for this preprint (which was not certified by peer review) is the author/funder, who has granted medRxiv a license to display the preprint in

perpetuity.
It is made available under a CC-BY 4.0 International license.

We expand the model structure presented above to incorporate and test the impact of different vaccination strategies in the model (see supporting information for full model structure description). Using the best calibrated model as baseline we introduce four vaccination scenarios, where we combine different levels of vaccine coverage among livestock and humans as well as frequency of campaign roll-out. As follows,

a) $80 \%$ of livestock in a single campaign approach

b) $80 \%$ of livestock yearly

c) $80 \%$ farmers

d) $50 \%$ farmers

Each intervention is introduced at year 5 of the simulation, with a linear scale up period of three months. The impact of vaccination is measured as the number of human CCHFV infections averted, and early human deaths averted. To assess efficiency of each approach, we also calculate the ratio of total vaccine courses over human infections averted..

\section{Results}

According to our systematic comparison of environmental and epidemiological drivers, a model with Saturation Deficit as a surrogate indicator of tick activity, and an assumption of increased CCHFV reporting capacity, resulted in the best, most parsimonious model fit when assessed with DIC. Figure 2 shows model outputs for the best performing model against calibration targets. Interestingly, the DIC estimate was very close (within 5 units) for most environmental drivers (see Table 3). Only relative humidity displayed a markedly worst fitting scenario. On the other hand, the baseline assumption of increased reporting capacity of human CCHFV was consistently superior to other epidemiological assumptions like the sustained influx of livestock from high endemic areas (Table 3). These results suggest a zoonotic endemic transmission that is well captured by the oscillations in the saturation deficit index. In humans, the spill-over would follow the same trend and more importantly, we estimate that only $31 \%(\mathrm{Crl} 95 \% 28 \%-33 \%)$ of cases would result in symptomatic disease (Figure S8).

We compare vaccination campaigns directed to animals only, humans only and also combinations of the two and with different campaign frequency. A summary of the overall impact of different vaccination approaches can be found in Table 4. Overall, vaccination strategies targeted to humans display a much larger impact (as human cases and deaths averted) compared to animal vaccination campaigns. Our results also suggest that human vaccination is a more efficient approach, reflected in less courses per human case averted: a single campaign for $80 \%$ livestock requires about 12 fold the number of courses to prevent one human case compared to a vaccine campaign reaching $50 \%$ of humans (Table 4, Figure 3). When we compare campaigns targeted to the overall population vs. farmers it is evident that targeting the high risk groups (farmers) results in higher efficiency (Figure 3D). An increase in the frequency of campaigns targeted to livestock displays a larger epidemiological impact, while resulting in more courses per case averted over time, compared to a single campaign as seen in panel B of Figure 3B. Finally, we simulated different combinations of vaccine efficacy and vaccine coverage for vaccination campaigns in humans (Figure 4). This analysis shows that for both deaths and infections averted, an intervention targeted to humans 
medRxiv preprint doi: https://doi.org/10.1101/2022.01.20.22269558; this version posted January 21, 2022. The copyright holder for this preprint (which was not certified by peer review) is the author/funder, who has granted medRxiv a license to display the preprint in

It is made available under a CC-BY 4.0 International license.

yields benefits that are at least one order of magnitude larger compared to the livestock campaign. Importantly, the contour plots show that there is a frontier of high effectiveness that can be reached within a spectrum of combinations of efficacy and coverage.

\section{Discussion}

Understanding the dynamics and epidemiological drivers of transmission are key to establishing priorities for the research and development roadmap for CCHFV. Here we present for the first time a calibrated mathematical model to simulate the transmission of CCHFV in livestock and spill-over into humans in western Afghanistan.

We find that CCHFV in Herat province has reached an endemic state of transmission within livestock, with a yearly cycle that is well reproduced by the oscillations of the saturation deficit index in this geographical area. This index incorporates air temperature and relative humidity, and indicates that the dry and hot months of summer likely result in periods of high tick activity. As long as tick activity data is mostly absent, this approach will continue to be necessary in the future. We highlight the need to extend this analysis to areas where other environmental drivers could be relevant, or where epidemiological factors result in different types of outbreaks. Spill-over transmission into humans mirrors this seasonal pattern, and although stochastic events explain some of the year-to-year variability, the increasing trend in case reporting appears strongly linked to the increased reporting capacity in the country at the time 13. Importantly, our results show that the volume of spill-over transmission might be much higher than previously expected: we estimate that $31 \%$ ( $\mathrm{Crl} 95 \% 28 \%-33 \%)$ of transmission events into humans lead to symptomatic disease and therefore to case reporting. Previous evidence from seroprevalence surveys have estimated higher fractions (ranging $88 \%-100 \%$ ) of sub-clinical presentation of CCHFV in humans when contrasted to reported cases ${ }^{20,21}$.

Future vaccine campaigns against CCHFV might have the largest population impact when applied to humans instead of animals. In the current study setting, immunisation strategies targeted to farmers (the high risk group) are more efficient as they require less courses per case averted. It is plausible that other epidemic settings with a more concentrated profile of risk could lead not only to more efficient but more impactful targeted interventions. The latter might require further investigation.

Our results exemplify the challenges posed by animal vaccination: livestock campaigns have a rapid impact, but their effect rapidly wanes as livestock population turnover prevents further accumulation of population immunity. More frequent vaccination campaigns increase the long term impact but not enough to match interventions directed to humans. Another challenge that might arise from a livestock vaccination campaign has to do with the fact that asymptomatic CCHFV infection in livestock might result in poor compliance from farmers and animal owners, as immunisation for innocuous infections will not be a priority. Finally, animal vaccination not only shows in our study to return lower benefits, but it also requires a much larger number of vaccine courses per human case averted.

The current study is restricted to one location, and our assessment of environmental drivers could yield different results in different ecological and climatic settings. Another limitation directly related to this is the lack of data on tick activity and tick abundance for this setting. Such data are rare not only in this context but in any setting around the world. Furthermore, 
medRxiv preprint doi: https://doi.org/10.1101/2022.01.20.22269558; this version posted January 21,2022 . The copyright holder for this preprint (which was not certified by peer review) is the author/funder, who has granted medRxiv a license to display the preprint in It is made available under a CC-BY 4.0 International license .

by not incorporating an explicit tick-vertebrate or tick-human mechanism in the model there is a possibility that other factors affecting tick populations or tick activity could result in different epidemic trajectories. However, a strength of our analysis is the solution we provide by systematically testing environmental surrogates for tick activity using climatic factors that are well known predictors of tick activity ${ }^{22}$. There is a clear need to collect and analyse tick activity in addition to wildlife host data to better understand the drivers of CCHFV transmission ${ }^{23}$.

Our approach focuses on the transmission into humans from human-animal contact, and we ignore human-to-human transmission. Previous evidence shows that human-to-human transmission is plausible and nosocomial transmission has been reported before ${ }^{24,25}$. However, we expect this aspect of transmission to contribute marginally to the annual reported trends of CCHFV cases in Afghanistan as most infections arise outside the hospital environment and are linked to animal handling activities ${ }^{15,16}$.

Our assumption on transmission is also central for interpreting the impact of vaccination campaigns, since the absolute epidemiological impact is necessarily limited by the population size of the targeted human group. For this reason, a measure of efficiency like doses per case averted might be a better indicator of intervention performance.

In this work we also ignore transmission cycles in wildlife. This can be important for maintaining more stable levels of endemicity, but the absence of data prevents us from designing a more complex transmission network for Herat.

In conclusion, CCHFV is likely to be already endemic in western Afghanistan, with a seasonal pattern which is robustly predicted by climatic factors which we explore in this work. The increasing number of human cases reported in Herat are most likely explained by increasing trends in reporting capacity in the country, and more importantly, these cases are reflecting only a fraction of the overall volume of human infection. Vaccination campaigns in humans are more impactful and efficient in the medium and long term compared to livestock vaccination. Finally, targeted campaigns to groups with increased risk of infection, like farmers, are the most efficient strategies in our assessment and should be a key component of future vaccine implementation roadmaps for CCHFV. 
medRxiv preprint doi: https://doi.org/10.1101/2022.01.20.22269558; this version posted January 21, 2022. The copyright holder for this preprint (which was not certified by peer review) is the author/funder, who has granted medRxiv a license to display the preprint in

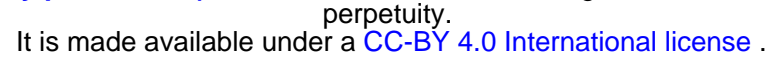

\section{References}

$1 \quad$ World Health Organization. An R\&D blueprint for action to prevent epidemics. Geneva. 2016. https://www.who.int/blueprint/about/r_d_blueprint_plan_of_action.pdf (accessed Nov 23, 2021).

2 Estrada-Peña A, Vatansever Z, Gargili A, Ergönul Ö. The trend towards habitat fragmentation is the key factor driving the spread of Crimean-Congo haemorrhagic fever. Epidemiol Infect 2010; 138: 1194-203.

3 Vescio FM, Busani L, Mughini-Gras L, et al. Environmental correlates of CrimeanCongo haemorrhagic fever incidence in Bulgaria. BMC Public Health 2012; 12. DOI:10.1186/1471-2458-12-1116.

4 Estrada-Peña A, Vatansever Z, Gargili A, Buzgan T. An early warning system for Crimean-Congo haemorrhagic fever seasonality in Turkey based on remote sensing technology. Geospat Health 2007; 2: 127-35.

5 Hassanein KM, El-Azazy OME, Yousef HM. Detection of Crimean-Congo haemorrhagic fever virus antibodies in humans and imported livestock in Saudi Arabia. Trans $R$ Soc Trop Med Hyg 1997; 91: 536-7.

6 Jameson LJ, Ramadani N, Medlock JM. Possible drivers of Crimean-Congo hemorrhagic fever virus transmission in Kosova. Vector Borne Zoonotic Dis 2012; 12 : 753-7.

7 Dowall S, Carroll M, Hewson R. Development of vaccines against Crimean-Congo haemorrhagic fever virus. Vaccine 2017; 35: 6015-23.

8 Christova I, Kovacheva O, Georgieva G, Ivanova S, Argirov D. Vaccine against congo-crimean haemorrhagic fever virus-bulgarian input in fighting the disease. Probl Infect Parasit Dis 2010; : 7-8.

9 Canakoglu N, Berber E, Tonbak S, et al. Immunization of knock-out $\alpha / \beta$ interferon receptor mice against high lethal dose of Crimean-Congo hemorrhagic fever virus with a cell culture based vaccine. PLoS Negl Trop Dis 2015; 9.

DOI:10.1371/JOURNAL.PNTD.0003579.

10 Spik K, Shurtleff A, McElroy AK, Guttieri MC, Hooper JW, Schmaljohn C. Immunogenicity of combination DNA vaccines for Rift Valley fever virus, tick-borne encephalitis virus, Hantaan virus, and Crimean Congo hemorrhagic fever virus. Vaccine 2006; 24: 4657-66.

11 Farzani TA, Földes K, Ergünay K, Gurdal H, Bastug A, Ozkul A. Immunological Analysis of a CCHFV mRNA Vaccine Candidate in Mouse Models. Vaccines 2019; 7. DOI:10.3390/VACCINES7030115.

12 Ghiasi SM, Salmanian AH, Chinikar S, Zakeri S. Mice orally immunized with a transgenic plant expressing the glycoprotein of Crimean-Congo hemorrhagic fever virus. Clin Vaccine Immunol 2011; 18: 2031-7.

13 Sahak M, Arifi F, Saeedzai S. Descriptive epidemiology of Crimean-Congo Hemorrhagic Fever (CCHF) in Afghanistan: Reported cases to National Surveillance System, 2016-2018. Int J Infect Dis 2019; 88: 135-40.

14 Al-Abri SS, Abaidani I Al, Fazlalipour M, et al. Current status of Crimean-Congo haemorrhagic fever in the World Health Organization Eastern Mediterranean Region: issues, challenges, and future directions. Int J Infect Dis 2017; 58: 82.

15 Mofleh J, Ahmad Z. Crimean-Congo haemorrhagic fever outbreak investigation in the Western Region of Afghanistan in 2008. East Mediterr Health J 2012; 18: 522-6.

16 Niazi A, Jawad M, Amirnajad A, Durr P, Williams D. Crimean-Congo Hemorrhagic Fever, Herat Province, Afghanistan, 2017. Emerg Infect Dis 2019; 25: 1596-8.

17 Mustafa ML, Ayazi E, Mohareb E, et al. Crimean-Congo Hemorrhagic Fever, Afghanistan, 2009. Emerg Infect Dis 2011; 17: 1940. 
medRxiv preprint doi: https://doi.org/10.1101/2022.01.20.22269558; this version posted January 21, 2022. The copyright holder for this preprint (which was not certified by peer review) is the author/funder, who has granted medRxiv a license to display the preprint in perpetuity.

It is made available under a CC-BY 4.0 International license .

18 Hyalomma marginatum - Factsheet for experts.

https://www.ecdc.europa.eu/en/disease-vectors/facts/tick-factsheets/hyalommamarginatum (accessed Dec 22, 2021).

19 Valcárcel F, González J, González MG, et al. insects Comparative Ecology of Hyalomma lusitanicum and Hyalomma marginatum Koch, 1844 (Acarina: Ixodidae). DOI:10.3390/insects11050303.

20 Bodur H, Akinci E, Ascioglu S, Öngürü P, Uyar Y. Subclinical Infections with CrimeanCongo Hemorrhagic Fever Virus, Turkey. Emerg Infect Dis 2012; 18: 640.

21 Papa A, Sidira P, Larichev V, et al. Crimean-Congo hemorrhagic fever virus, Greece. Emerg Infect Dis 2014; 20: 288-90.

22 Estrada-Peña A, Jameson L, Medlock J, Vatansever Z, Tishkova F. Unraveling the ecological complexities of tick-associated crimean-congo hemorrhagic fever virus transmission: A gap analysis for the western palearctic. Vector-Borne Zoonotic Dis 2012; 12: 743-52.

23 Mertens M, Schuster I, Sas MA, et al. Crimean-Congo Hemorrhagic Fever Virus in Bulgaria and Turkey. Vector Borne Zoonotic Dis 2016; 16: 619-23.

24 Pshenichnaya NY, Nenadskaya SA. Probable Crimean-Congo hemorrhagic fever virus transmission occurred after aerosol-generating medical procedures in Russia: nosocomial cluster. Int J Infect Dis 2015; 33: 120-2.

25 Maltezou HC, Papa A, Ventouri S, et al. A case of Crimean-Congo haemorrhagic fever imported in Greece: Contact tracing and management of exposed healthcare workers. J Infect Prev 2019; 20: 171-8.

26 Gonzalez J, Camicas J, Cornet J, virology MW-R in, 1998 undefined. Biological and clinical responses of West African sheep to Crimean-Congo haemorrhagic fever virus experimental infection. Elsevier DOI:10.1016/S0923-2516(99)80013-2.

27 Barthel R, Mohareb E, Younan R, et al. Seroprevalance of Crimean-Congo haemorrhagic fever in Bulgarian livestock. Taylor Fr 2014; 28: 540-2.

28 Bente DA, Forrester NL, Watts DM, McAuley AJ, Whitehouse CA, Bray M. CrimeanCongo hemorrhagic fever: history, epidemiology, pathogenesis, clinical syndrome and genetic diversity. Antiviral Res 2013; 100: 159-89.

29 Fillâtre $\mathrm{P}$, Revest M, Tattevin P. Crimean-Congo hemorrhagic fever: An update. Med Mal Infect 2019; 49: 574-85.

30 FAO. Afghanistan national livestock census 2002-2003. Rome, 2008 https://www.fao.org/3/i0034e/i0034e01.pdf (accessed Jan 11, 2022).

31 World Bank. Fertility rate, total (births per woman) - Mexico | Data. 2019.

32 Climate reanalysis | ECMWF. https://www.ecmwf.int/en/research/climate-reanalysis (accessed Dec 22, 2021).

33 Climate reanalysis | Copernicus. https://climate.copernicus.eu/climate-reanalysis (accessed Dec 22, 2021).

34 MODIS Subsets | Earthdata. https://earthdata.nasa.gov/earth-observation-data/nearreal-time/rapid-response/modis-subsets (accessed Dec 22, 2021). 
medRxiv preprint doi: https://doi.org/10.1101/2022.01.20.22269558; this version posted January 21, 2022. The copyright holder for this preprint (which was not certified by peer review) is the author/funder, who has granted medRxiv a license to display the preprint in

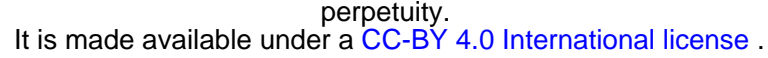

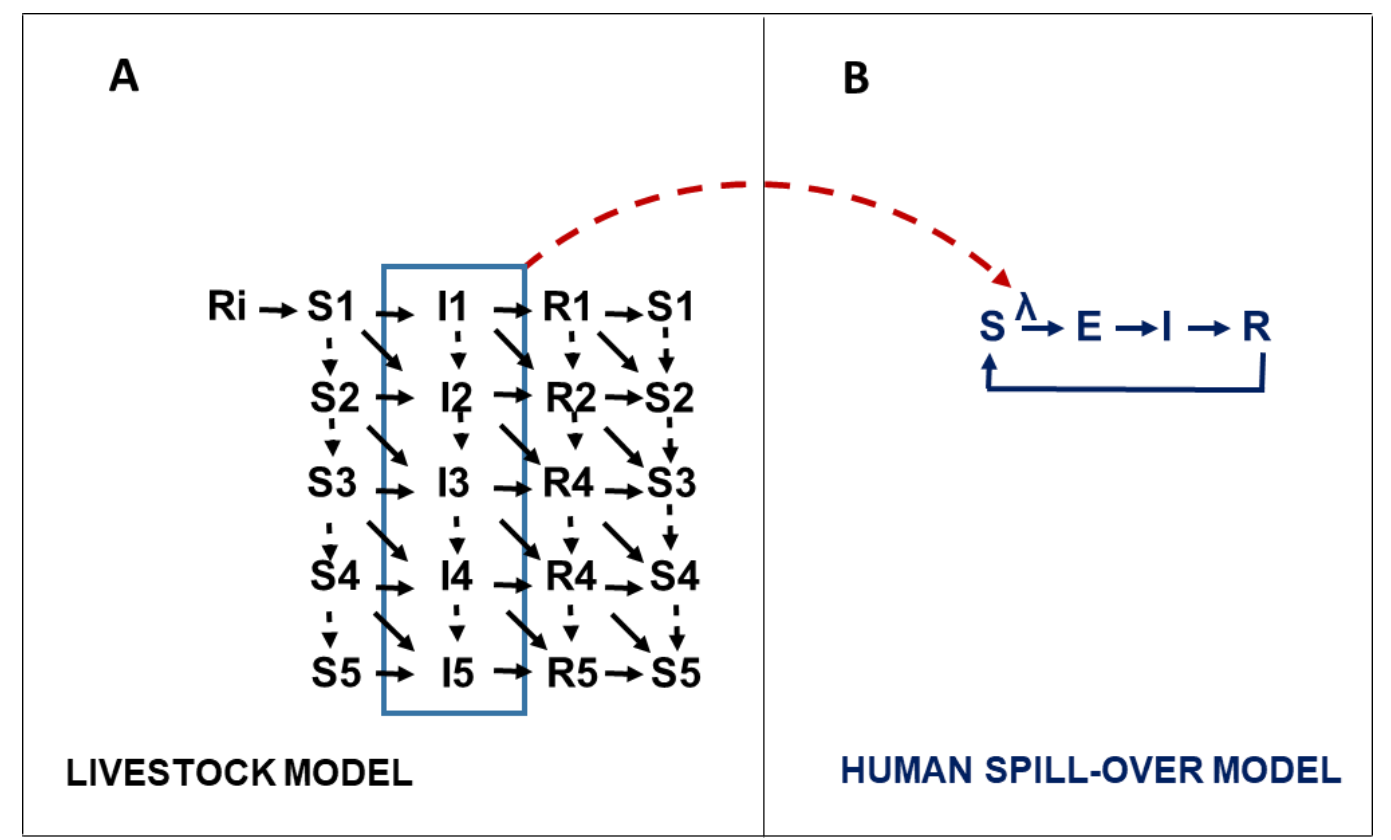

Figure 1: Mode schematic of CCHFV transmission

We modelled CCHFV viral transmission between livestock, and from livestock to humans. In panel A, livestock were stratified in five yearly age-groups. Animals are born into the model at a rate proportional to mortality to maintain equilibrium. A fraction of livestock will acquire immunity through colostrum exposure in the first days after birth, here denoted as compartment $\mathrm{Ri}$, the remaining fraction will enter the model through $\mathrm{S} 1$. The fraction moving to Ri is proportional to CCHFV prevalence at each time $t$. We assume a colostrum acquired immunity loss after six months. Susceptible livestock acquire the infection as a function of infection prevalence and a scaled time-varying environmental driver. Infectious stage (I) leads to a recovery compartment $(R)$. We assume waning immunity with an average rate of 5 years ${ }^{-1}$, hence the transition $\mathrm{R}->\mathrm{S}$. In panel $\mathrm{B}$, we formulate the human spillover structure as an SEIRS model, governed by a series of stochastic transition events. Transmission follows a force of infection $\lambda$, that is defined by the infectious livestock prevalence at time $t \sum_{\{a=1\}}^{5} \frac{I_{a}}{N}$

and a relative risk of transmission that conveys the differential risk by human occupation (i.e., farmers, and other). This connecting link is represented by the red dashed arrow connecting the two models. This implies a sequence of events in the runtime in which a realisation of the animal model is run over the time period, producing a vector of prevalence as output. This vector is subsequently passed as an input to the human spillover model. From the structure in panel $\mathrm{B}$, is also evident that we allow a loss of acquired immunity R->S. 
medRxiv preprint doi: https://doi.org/10.1101/2022.01.20.22269558; this version posted January 21, 2022. The copyright holder for this preprint (which was not certified by peer review) is the author/funder, who has granted medRxiv a license to display the preprint in perpetuity.

It is made available under a CC-BY 4.0 International license.

A

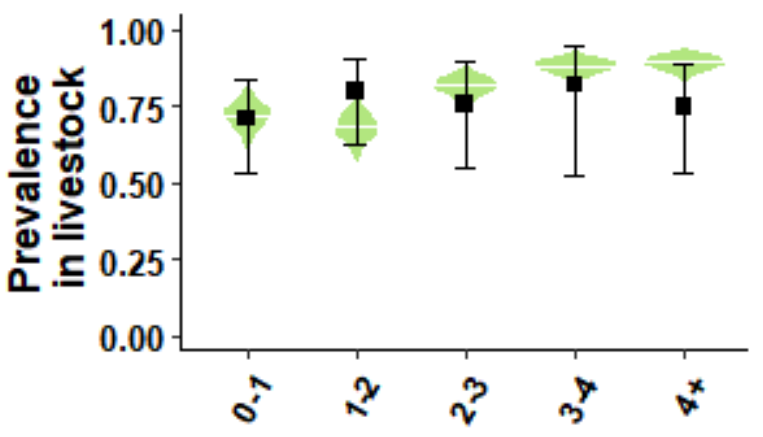

Age group (years)

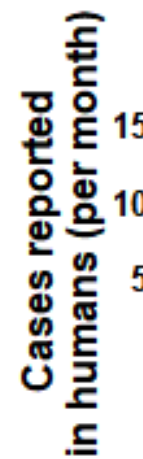

B

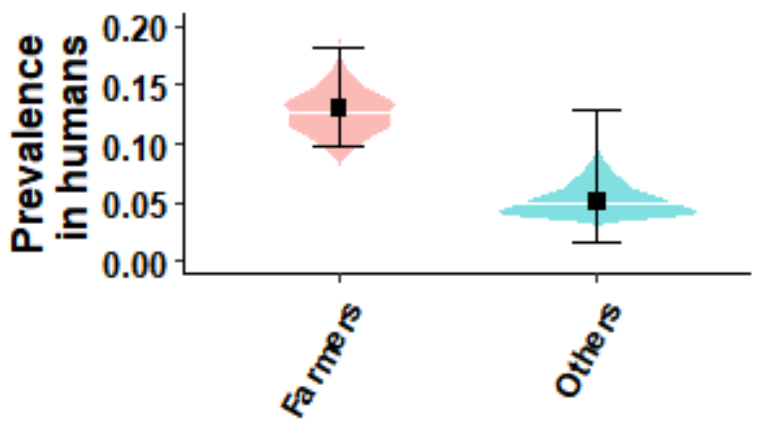

C

$\begin{array}{r}150 \\ 100- \\ 50- \\ 0\end{array}-$
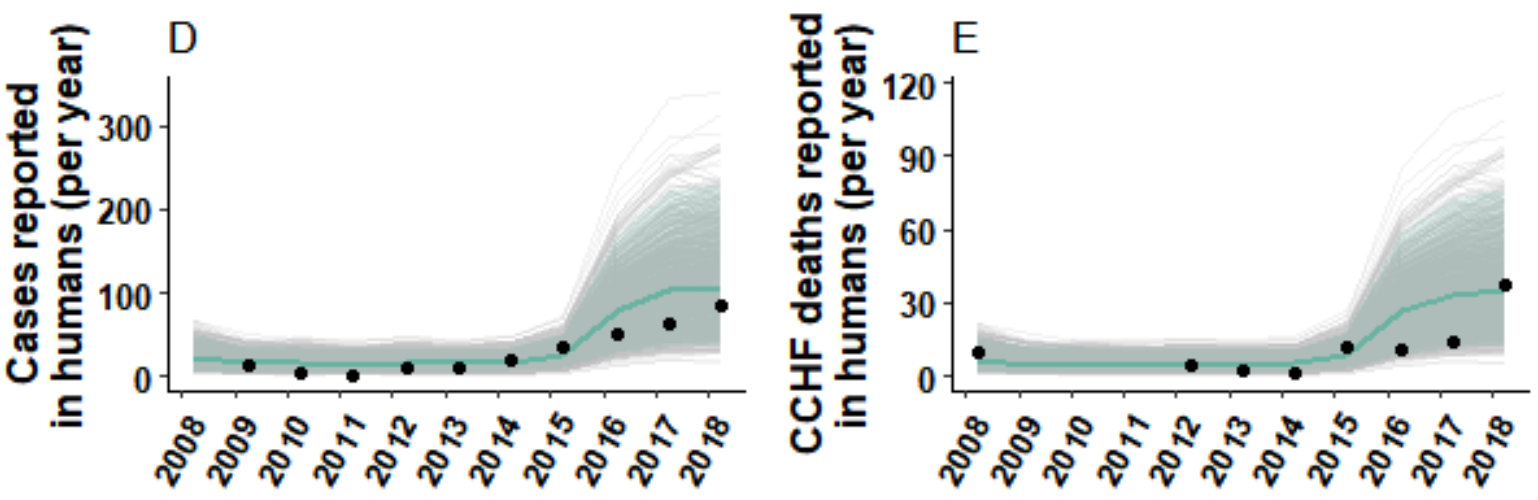

Figure 2: Model trajectories against calibration target data

Panel A shows the age stratified simulated CCHFV IgG prevalence among livestock (green density plot), with the median estimate (white horizontal line), against IgG prevalence data for the same age groups as reported by Mustafa et al 17 from Herat (black square shows the mean and error bars the $95 \% \mathrm{Cl}$ ). Panel B shows the posterior density and median estimate of IgG prevalence for the population of farmers and other occupations (density plots pink and blue) against IgG prevalence data from Herat reported. We take the prevalence estimate to match the dates of data collection as reported by Mustafa et al. Panel $\mathrm{C}$ shows stochastic model trajectories (grey lines) for monthly incident CCHFV human cases reported in Herat. In shaded pale grey, the $95 \% \mathrm{Crl}$ and in solid blue, the median estimate. In black dots, monthly incident cases reported in two separate CCHF outbreaks in Herat: in 2008 as reported by Mofleh et al ${ }^{15}$, and $2017-2018$ as reported by Niazi et al, and Sahak et al ${ }^{13,16}$. In Panels D and E, yearly CCHF cases and deaths reported from Herat, against data (black) as reported by Sahak et al. 
medRxiv preprint doi: https://doi.org/10.1101/2022.01.20.22269558; this version posted January 21,2022 . The copyright holder for this preprint (which was not certified by peer review) is the author/funder, who has granted medRxiv a license to display the preprint in perpetuity.

It is made available under a CC-BY 4.0 International license.
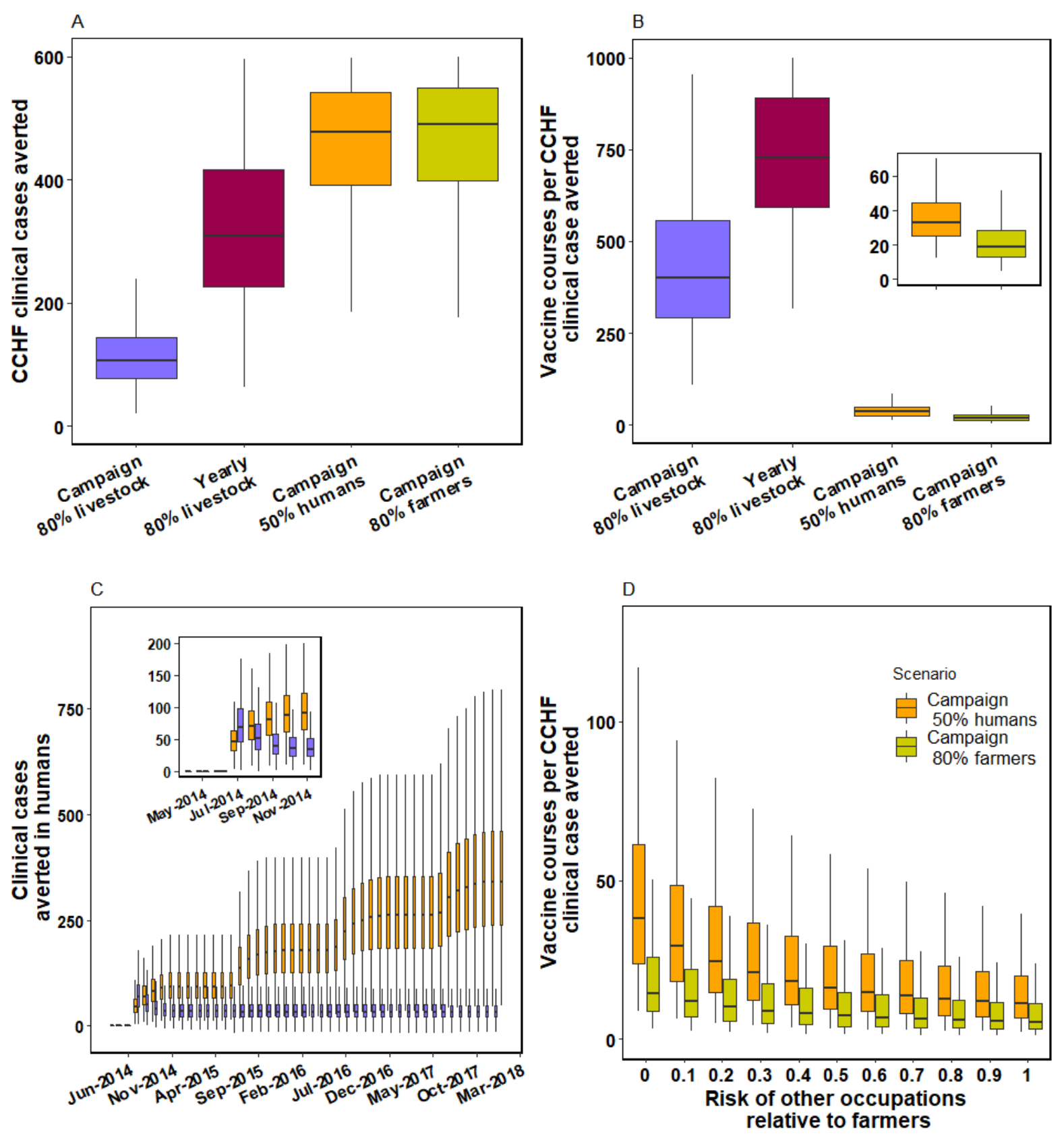

Figure 3. Population impact of CCHF vaccination strategies

In panel A, cumulative clinical cases averted over 4 years of simulation, for four different scenarios of intervention. In panel $\mathrm{B}$, the number of vaccine courses required to avert a CCHFV case in humans, estimated as the ratio number of courses over clinical cases averted. The inset window shows a zoom-in for clarity of the two human vaccination interventions. In panel $\mathrm{C}$, boxplots for the cumulative number of averted clinical cases of CCHFV for the first 4 years of the simulated vaccine period. Inset window shows a zoom-in into the first seven months after vaccination campaigns. In orange, a one-off campaign for vaccinating $50 \%$ of humans over a three-month period. In purple, a one-off campaign to vaccinate $80 \%$ of livestock over a three-month scale-up period. Finally in panel $\mathrm{D}$, sensitivity analysis assessing the effect of the disparity in risk between farmers and other occupations. As seen, a same level of risk between groups $(R R=1)$ implies a larger number of cases averted for the same number of courses in both types of campaign. 
medRxiv preprint doi: https://doi.org/10.1101/2022.01.20.22269558; this version posted January 21, 2022. The copyright holder for this preprint (which was not certified by peer review) is the author/funder, who has granted medRxiv a license to display the preprint in perpetuity.

It is made available under a CC-BY 4.0 International license.

A

\begin{tabular}{llll} 
CCHF infections averted & & & \\
\hline & 500 & 1000 & 1500
\end{tabular}

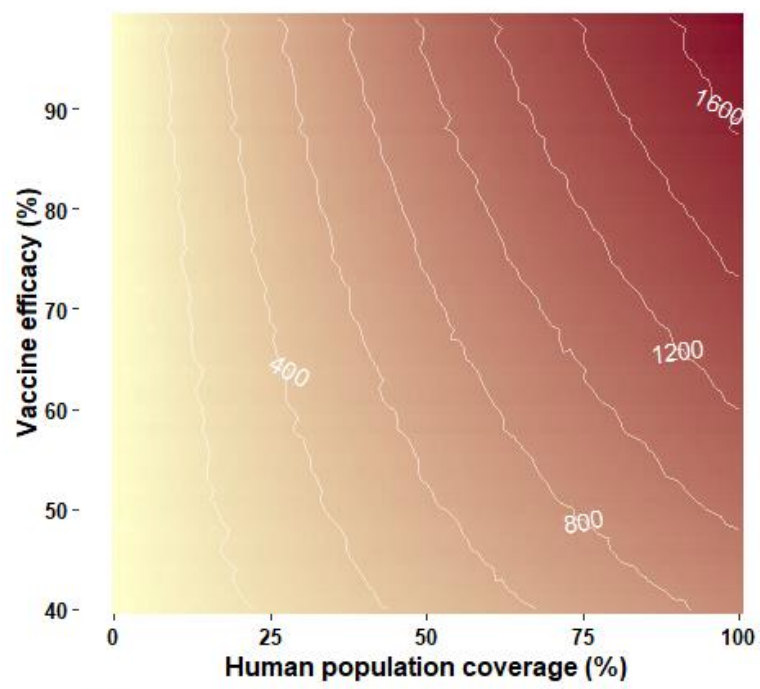

C

\begin{tabular}{llllll} 
& CCHF infections averted & & & & \\
\hline & 400 & 800 & 1200 & 1000
\end{tabular}

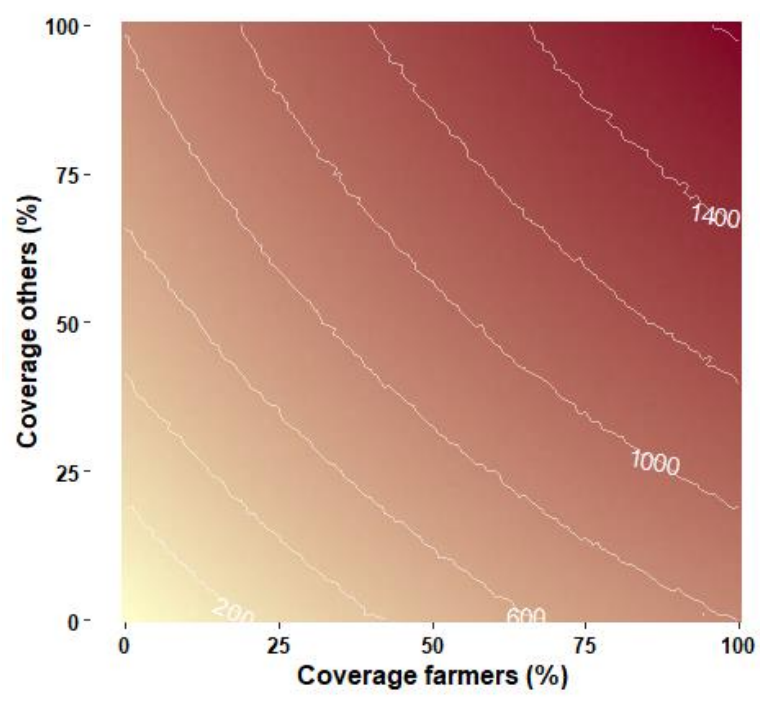

B
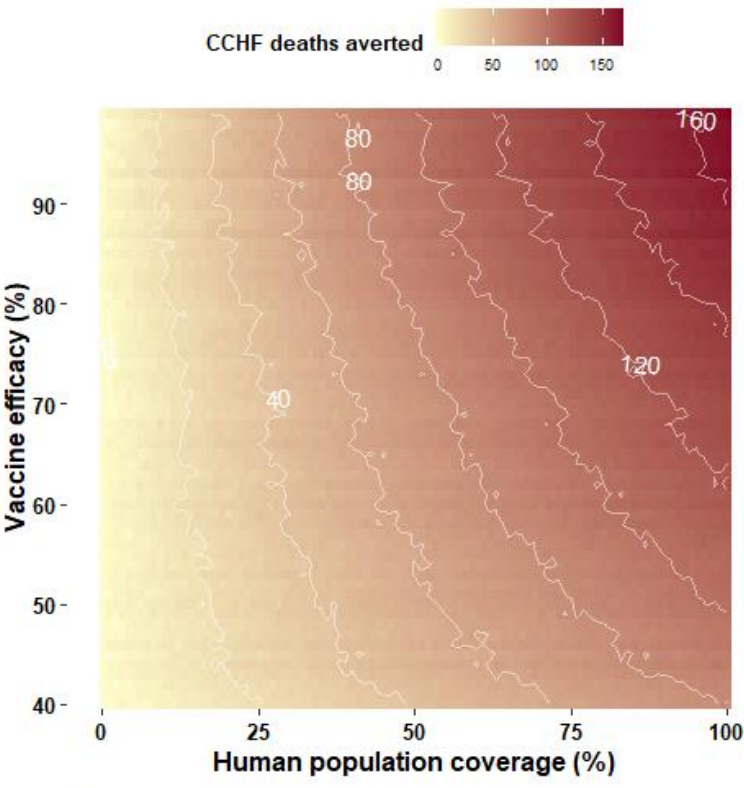

D

Courses per CCHF case averted

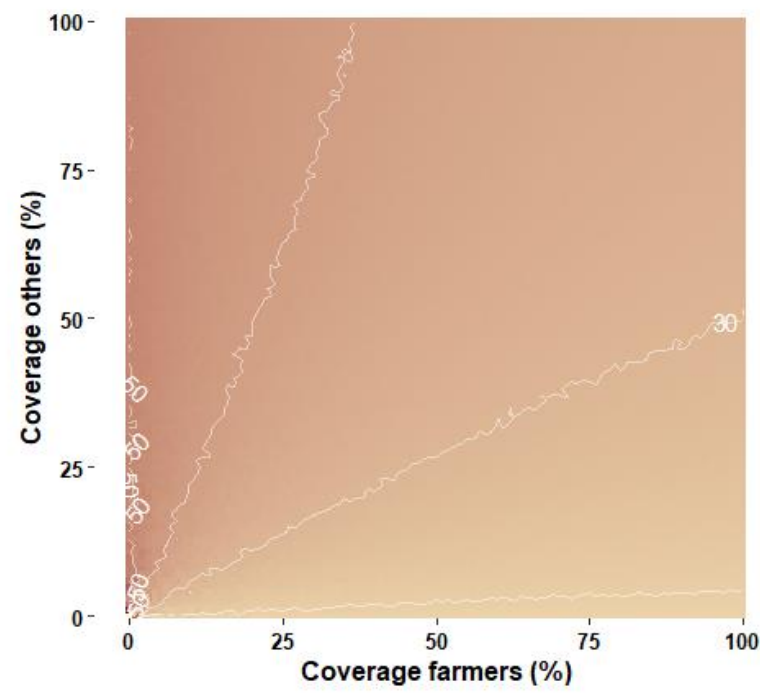

Figure 4. Exploration of vaccine efficacy and coverage on incidence and mortality reductions. In panel $A$, a contour for combinations of vaccine efficacy and vaccine coverage among humans. Interventions are introduced as a single campaign approach. White solid lines reflect the frontier of effect measured as CCHFV infections averted. Panel B shows the combination efficacy vs human vaccination coverage and effect measured as CCHFV deaths averted. In panels $C$ and $D$, the effect of different levels of coverage among farmers and other occupations on infections averted and doses per case averted (D). 
medRxiv preprint doi: https://doi.org/10.1101/2022.01.20.22269558; this version posted January 21, 2022. The copyright holder for this preprint (which was not certified by peer review) is the author/funder, who has granted medRxiv a license to display the preprint in

It is made available under a CC-BY 4.0 International license.

Table 1: Model parameters

\begin{tabular}{|c|c|c|c|}
\hline Parameter description & Notation & Input Values/Estimated ${ }^{*}$ & Source \\
\hline \multicolumn{4}{|l|}{$\begin{array}{l}\text { Natural history of disease } \\
\text { Livestock }\end{array}$} \\
\hline Duration of infectiousness in livestock & $D_{i L}$ & 7 days & $\begin{array}{l}\text { Gonzalez et al., } \\
1998^{26}\end{array}$ \\
\hline $\begin{array}{l}\text { Duration of colostrum acquired immunity } \\
\text { (months) }\end{array}$ & $D_{a L}$ & $8.3(\mathrm{Crl} 95 \% 2-10)$ & Estimated \\
\hline $\begin{array}{l}\text { Mean time to loss of immunity in adult } \\
\text { livestock (months) }\end{array}$ & $D_{m L}$ & 52 (Crl 95\% 46-76) & Estimated \\
\hline $\begin{array}{l}\text { Proportion of livestock immune at time } 0 \\
\text { by age }{ }^{\text {group }} \text { a }\end{array}$ & $R_{a}(t)$ & $R_{a}(t)=\left\{\begin{array}{cl}0.29 & \text { for } a=1 \\
0.48 & \text { fora }=2 \\
0.8 & \text { for }=3 \\
0.87 & \text { for } a=4 \\
0.87 & \text { for } a=5\end{array}\right.$ & $\begin{array}{l}\text { Barthel et al., } \\
2014^{27}\end{array}$ \\
\hline \multicolumn{4}{|l|}{ Humans } \\
\hline Duration of latent period in humans & $D_{l H}$ & 4 days & $\begin{array}{l}\text { Bente et al., } \\
2013^{28}\end{array}$ \\
\hline Duration of infectiousness in humans & $D_{i H}$ & 9 days & $\begin{array}{l}\text { Fillâtre et al., } \\
2019^{29}\end{array}$ \\
\hline Duration of immunity in humans & $D_{m H}$ & 3650 days & Assumption \\
\hline $\begin{array}{l}\text { Fraction of human infection resulting in a } \\
\text { clinical case }\end{array}$ & $\phi$ & 0.31 (Crl 95\% 0.28-0.33) & Estimated \\
\hline Proportion of farmers immune at time 0 & $\mathrm{p}_{\mathrm{F}}$ & 0.1333 & $\begin{array}{l}\text { Mustafa et al., } \\
2011^{17}\end{array}$ \\
\hline Proportion of others immune at time 0 & po & 0.0469 & $\begin{array}{l}\text { Mustafa et al., } \\
2011^{17}\end{array}$ \\
\hline Case fatality rate of $\mathrm{CCHF}$ & $C F R_{c c h f v}$ & 0.33 & $\begin{array}{l}\text { Niazi et al., } \\
2019^{16}\end{array}$ \\
\hline \multicolumn{4}{|l|}{ Demographics } \\
\hline Livestock population size & $N_{L}$ & 15,193 & FAO $2008^{30}$ \\
\hline Livestock ageing factor (1/months) & $\delta$ & $1 / 12$ & Assumption \\
\hline Livestock monthly death rate & $\mu$ & $\mu_{a}= \begin{cases}0.0761 & \text { for } a=1 \\
0.0743 & \text { for } a=2 \\
0.0746 & \text { fora }=3 \\
0.0744 & \text { for } a=4 \\
0.0747 & \text { for } a=5\end{cases}$ & $\begin{array}{l}\text { See livestock } \\
\text { demographic } \\
\text { model (fig S4) }\end{array}$ \\
\hline Population size - Farmers & $\mathrm{N}_{\mathrm{F}}$ & 7,614 & USAID 2008 \\
\hline Population size - Other occupations & No & 17,768 & USAID 2008 \\
\hline Life expectancy - humans & $\mathrm{LH}_{\mathrm{H}}$ & 61.5 years & $\begin{array}{l}\text { World bank } \\
2008-2014^{31}\end{array}$ \\
\hline Monthly birth rate humans & $\mathrm{b}_{\mathrm{H}}$ & $1 /\left(12^{*} 61.5\right)$ & Assumption \\
\hline Monthly birth rate in livestock & $b_{L}$ & $\mu$ & Assumption \\
\hline \multicolumn{4}{|l|}{ Viral transmission parameters } \\
\hline $\begin{array}{l}\text { Between livestock transmission } \\
\text { temperature dependent }\end{array}$ & A & $0.33(\mathrm{Crl} 95 \% 0.2-0.4)$ & Estimated \\
\hline Transmission from livestock to farmers & $\beta_{F}$ & $0.28(\mathrm{Crl} 95 \% 0.15-0.34)$ & Estimated \\
\hline $\begin{array}{l}\text { Transmission from livestock to other } \\
\text { occupational groups }\end{array}$ & $\mathrm{O}$ & $0.3(\mathrm{Crl} 95 \% 0.1-0.5)$ & Estimated \\
\hline \multicolumn{4}{|l|}{ Vaccination parameters } \\
\hline Vaccine efficacy & $\mathrm{K}$ & $90 \%$ & Assumption \\
\hline Time to vaccine protection & $D_{p V}$ & $X X ?$ & Assumption \\
\hline
\end{tabular}

${ }^{*}$ Estimated values represent the parameter values for the best most parsimonious model, i.e., saturation deficit obtained during calibration.

$¥$ Livestock age stratification groups where $a=1$ reflects 0 to 12 months; $a=2$ for 13 to 24 months; $a=3$ for 25 to 36 months; $a=4$ for 37 to 48 months, $a=5$ for 48 months and older 
medRxiv preprint doi: https://doi.org/10.1101/2022.01.20.22269558; this version posted January 21, 2022. The copyright holder for this preprint (which was not certified by peer review) is the author/funder, who has granted medRxiv a license to display the preprint in perpetuity.

It is made available under a CC-BY 4.0 International license.

Table 2: Environmental drivers as surrogate markers of tick activity

\begin{tabular}{|c|c|c|c|}
\hline $\begin{array}{l}\text { Environmenta } \\
\text { I indicator }\end{array}$ & Description & $\begin{array}{l}\text { How we modelled } \\
\text { it }\end{array}$ & Source of data \\
\hline $\begin{array}{l}\text { Soil temperature } \\
\text { (ST)(Celsius) }\end{array}$ & $\begin{array}{l}\text { Temperature of the soil in the } \\
\text { first layer }(0-7 \mathrm{~cm}) \text { taken at } \\
10: 00 \mathrm{AM}\end{array}$ & $\begin{array}{l}\text { Vector of monthly } \\
\text { average from April } 2008 \\
\text { to January } 2019 \text {. We } \\
\text { assume a tick activity } \\
\text { range between } 12^{\circ} \mathrm{C} \text { and } \\
30^{\circ} \mathrm{C} \text {. }\end{array}$ & $\begin{array}{l}\text { ERA5 atmospheric } \\
\text { variables, centred in a } \\
\text { polygon in Herat } \\
\text { (ECMWF and } \\
\text { Copernicus }^{32}{ }^{33} \text { ) }\end{array}$ \\
\hline $\begin{array}{l}\text { Relative humidity } \\
(\mathrm{RH})\end{array}$ & $\begin{array}{l}\text { It is a measure of vapor } \\
\text { content in the air. }\end{array}$ & $\begin{array}{l}\text { Vector of monthly } \\
\text { average from April } 2008 \\
\text { to January } 2019 \text {. As ticks } \\
\text { prefer dry hot weather, } \\
\text { we use the complement } \\
\text { (1-RH) to indicate } \\
\text { increase in tick activity }\end{array}$ & $\begin{array}{l}\text { Constructed from air } \\
\text { temperature }(T) \text {, dew } \\
\text { point temperature }(T d), \\
\text { and surface pressure } \\
\text { from ERA5 (ECMWF and } \\
\left.\text { Copernicus }^{32}{ }^{33}\right)\end{array}$ \\
\hline $\begin{array}{l}\text { Saturation deficit } \\
\text { (SD) }\end{array}$ & $\begin{array}{l}\text { A measure of the drying power } \\
\text { of the air. It accounts both for } \\
\text { air temperature, vapor } \\
\text { pressure and relative humidity. }\end{array}$ & $\begin{array}{l}\text { Vector of monthly } \\
\text { average from April } 2008 \\
\text { to January } 2019 \text {. Given } \\
\text { that SD includes } \\
\text { temperature, we use a } \\
\text { simple regression model } \\
\text { to find the SD range of } \\
\text { tick activity matching the } \\
\text { ST range. }\end{array}$ & $\begin{array}{l}\text { ERA5 atmospheric } \\
\text { variables centred in a } \\
\text { polygon in Herat } \\
\text { (ECMWF and } \\
\text { Copernicus }^{32} \text { 33) }\end{array}$ \\
\hline $\begin{array}{l}\text { Normalised } \\
\text { difference } \\
\text { vegetation index } \\
\text { (NDVI) }\end{array}$ & $\begin{array}{l}\text { Combines satellites signals to } \\
\text { estimate the density of green } \\
\text { on an area of land. It indicates } \\
\text { a combination of rainfall, and } \\
\text { land change. }\end{array}$ & $\begin{array}{l}\text { Vector of monthly } \\
\text { average from April } 2008 \\
\text { to January } 2019 .\end{array}$ & $\begin{array}{l}\text { NASA, EarthData } \\
\text { (MODIS/VIIRS subsets) } \\
\text { for Herat }{ }^{44}\end{array}$ \\
\hline
\end{tabular}

Table 3: Model comparison using DIC

\begin{tabular}{|l|l|}
\hline Step 1: Selection of environmental driver assumption & DIC \\
\hline Saturation deficit & 65.21 \\
\hline NDVI & 69.1 \\
\hline Soil temperature & 70.05 \\
\hline Relative humidity & 86.81 \\
\hline $\begin{array}{l}\text { Step 2: Selection of Saturation deficit + Epidemiological } \\
\text { assumption }\end{array}$ & \\
\hline Improved reporting & 65.21 \\
\hline Increase influx of livestock (stable reporting) & 77.64 \\
\hline Increase influx of livestock and improved reporting over time & 79.05 \\
\hline
\end{tabular}


medRxiv preprint doi: https://doi.org/10.1101/2022.01.20.22269558; this version posted January 21 , 2022. The copyright holder for this preprint (which was not certified by peer review) is the author/funder, who has granted medRxiv a license to display the preprint in

perpetuity.
It is made available under a CC-BY 4.0 International license.

Table 4: CCHFV Infections and early deaths averted, and number of vaccine courses per clinical case averted, according to the four vaccination scenarios, cumulatively over the period April 2014 to Dec 2018.

\begin{tabular}{|l|l|l|l|l|l|}
\hline $\begin{array}{l}\text { Vaccination } \\
\text { scenario }\end{array}$ & $\begin{array}{l}\text { Human CCHF } \\
\text { infections } \\
\text { averted } \\
\text { (Crl 95\%) }\end{array}$ & $\begin{array}{l}\text { Human } \\
\text { clinical CCHF } \\
\text { cases averted } \\
\text { (Crl 95\%) }\end{array}$ & $\begin{array}{l}\text { Human CCHF } \\
\text { deaths } \\
\text { averted } \\
\text { (Crl 95\%) }\end{array}$ & $\begin{array}{l}\text { Total vaccine } \\
\text { courses* } \\
\text { (Crl 95\%) }\end{array}$ & $\begin{array}{l}\text { Vaccine } \\
\text { courses per } \\
\text { clinical case } \\
\text { averted } \\
\text { (Crl 95\%) }\end{array}$ \\
\hline $\begin{array}{l}\text { 80\% of livestock } \\
\text { in a single } \\
\text { campaign }\end{array}$ & $105(38-207)$ & $31(10-65)$ & $10(2-22)$ & $\begin{array}{l}12,578(8,857- \\
27,141)\end{array}$ & $431(162-1,438)$ \\
\hline $\begin{array}{l}80 \% \text { of livestock } \\
\text { yearly }\end{array}$ & $318(117-632)$ & $94(30-198)$ & $31(10-66)$ & $\begin{array}{l}108,948(73,236- \\
260,514)\end{array}$ & $1,243(465-$ \\
\hline $\begin{array}{l}50 \% \text { humans in } \\
\text { a single } \\
\text { campaign }\end{array}$ & $902(326-1832)$ & $266(88-568)$ & $87(28-185)$ & $\begin{array}{l}9,533(8,294- \\
10,241)\end{array}$ & $35(16-107)$ \\
\hline $\begin{array}{l}80 \% \text { farmers in a } \\
\text { single campaign }\end{array}$ & $686(270-1039)$ & $191(59-490)$ & $63(19-164)$ & $\begin{array}{l}3,700(3,060- \\
4,242)\end{array}$ & $19(7-62)$ \\
\hline
\end{tabular}

* Cumulative vaccine courses over simulation period 